\title{
PERBEDAAN PENERIMAAN DIRI ORANG TUA YANG MEMILIKI ABK BERDASARKAN KEIKUTSERTAAN DALAM KEGIATAN SUPPORT GROUP
}

\author{
Iriani indri Hapsari \\ Herdiyan Maulana
}

\begin{abstract}
The aim of this research was to analyse the differences between the self acceptence of parents with handicapped children based on their involvment in the support group compared to those without any involvement. In this research, 64 parents with handicapped children were selected using nonprobability sampling with incidental sampling type. The samples comprised of 32 parents with involvement in support group and the remaining were without any involvement. Adapted Berger Self Acceptance Scale was used for the measurement of the research. Independent sample T-Test was the statistical analysis method used for the research. The result showed that $t=0,267$ with $d f=$ $62 ; t<t$ able (2) and $p=0,79 ; p>0,05$, meaning Ho was accepted and H1 was rejected. The result showed that there is no significance different between self acceptence of parents with handicaped children who join the support group with those who have not joined the group. Discussion of this research concluded there are several factors influencing this finding, such as family, cultural problems, and religious view, beside social and economic status.
\end{abstract}

Key word: selfacceptance, support group, handicapped children.

\begin{abstract}
Abstrak
Tujuan penelitian ini adalah untuk menganalisis perbedaan antara penerimaan diri orang tua yang mempunyai anak berkebutuhan khusus (ABK) berdasarkan keikutsertaannya dalam kegiatan support group dibandingkan dengan mereka yang tidak ikut serta. Dalam penelitian ini 64 orang tua yang memiliki anak berkebutuhan khusus dipilih dengan menggunakan teknik sampel nonprobabilitas dengan tipe insidental sampling. Sampel terdiri dari 32 orang tua dengan keikutsertaan dalam support group dan sisanya adalah mereka yang ikut serta. Sebagai alat ukur digunakan Berger Self Acceptance Scale yang diadaptasi dan independent sample t-test digunakan sebagai metode analisis statistik. Hasil penelitian menunjukkan bahwa $\mathrm{t}=0,267$ dengan $\mathrm{df}=62 ; \mathrm{t}<$ table $(2)$ dan $\mathrm{p}=0,79 ; \mathrm{p}>0,05$, yang berarti H0 diterima dan H1 ditolak. Temuan ini menunjukkan tidak ada perbedaan yang signifikan antara penerimaan diri orang tua yang memiliki ABK dan mengikuti support group dengan mereka yang tidak mengikuti support group. Penelitian ini juga menyimpulkan terdapat beberapa faktor yang memperngaruhi temuan ini seperti keluarga, masalah budaya, dan pandangan agama di samping status sosial ekonomi.
\end{abstract}

Kata kunci: penerimaan diri, support group, anak berkebutuhan khusus

\section{PENDAHULUAN}

Setiap individu termasuk anak berkebutuhan khusus berhak mendapatkan pendidikan, hal ini diperkuat dalam Undang-undang Sistem Pendidikan Nasional No. 20 Tahun 2003 Pasal 5 Ayat 2 yang menyatakan bahwa warga negara yang memiliki kelainan fisik, emosional, mental, intelektual, dan/ atau sosial berhak mendapatkan pendidikan khusus.

Dalam pendidikan seorang anak, peran orang tua sangat penting apalagi bagi anak-anak yang berkebutuhan khusus. Hal ini disebabkan karena keterbatasan dan terhambatnya perkembangan yang dimiliki ABK. Tetapi faktanya tidak mudah bagi orang tua dalam mendidik anak dengan berkebutuhan khusus. Hal ini dikarenakan kurangnya informasi pengetahuan tentang bagaimana menangani kondisi anaknya, ditambah dengan anggapan negatif tentang kondisi anak yang seringkali diterima dan dirasakan. Memiliki anak berkebutuhan khusus, seringkali membuat orang tua merasa sedih, terasingkan, merasa 
bersalah, dan terhakimi. Membutuhkan waktu cukup lama untuk bisa menerima kondisi anak yang tidak bisa berkembang optimal layaknya anak normal lainnya, anak berkebutuhan khusus akan mengalami fase penolakan di awal. Bila penolakan ini terus berlanjut, orang tua secara tidak langsung akan sulit menerima keberadaan anak. Hal ini akan berdampak terhadap cara orang tua dalam mengasuh dan mendidik anaknya.

Orang tua akan cenderung menelantarkan dan mengabaikan pendidikan dan perkembangan anaknya. Berbeda dengan orang tua yang bisa menerima kondisi anaknya yang ABK, akan berusaha memberi perhatian, cinta kasih dan berusaha mencari informasi, serta memberi pendidikan yang terbaik bagi anaknya.

Pandangan bahwa penerimaan diri orang tua akan mempengaruhi optimalisasi perkembangan ABK diperkuat oleh pendapat dari Horney (dalam Denmark, 1973 ) yang mengungkapkan bahwa seseorang yang tidak menghargai dan menyayangi dirinya tidak akan bisa menyayangi dan menghargai orang lain.

Beberapa penelitian lainnya juga menunjukkan terdapat hubungan yang positif antara penerimaan diri dengan sikap positif. Dengan demikian, dapat ditarik kesimpulan bahwa kemampuan individu dalam menerima dirinya akan membawa pada sikap dan perilaku yang lebih positif kepada orang lain, termasuk dalam hal ini penerimaan orang tua pada anaknya yang ABK.

Contoh yang bisa dilihat tentang penerimaan diri orang tua terhadap optimalisasi perkembangan anak yang ABK adalah Lee Hee-Ah seorang pianis cilik yang hanya memiliki empat jari masing-masing tangannya hanya dua jari, selain memiliki kelainan fisik juga termasuk anak down syndromme dan keterbelakangan mental. Namun, berkat kegigihan orang tuanya memotivasi dirinya, Lee Hee-Ah tumbuh menjadi anak yang ceria dan bersemangat serta memiliki talenta menjadi pianis dunia. Namun, pada kenyataannya masih banyak orang tua yang belum atau tidak dapat menerima keberadaan anaknya yang termasuk ABK.

Perasaan orang tua yang shock dan stres terhadap keadaan anaknya memang tidak bisa diabaikan begitu saja, orang tua membutuhkan waktu untuk bisa menerima kondisi anaknya karena siapapun orang tua pasti menginginkan anaknya tumbuh dan berkembang secara normal. Oleh karena itu, dibutuhkan suatu cara atau wadah untuk membantu para orang tua menyikapi kondisi yang dihadapi serta mengurangi beban pikiran dan perasaan yang dialami.

Saat ini telah banyak sarana bagi para orang tua untuk bisa berbagi kisah yang dihadapi dengan sesama orang tua yang memiliki ABK atau dengan para ahli dan konselor. Biasanya terbentuk dalam kelompok-kelompok kecil maupun besar yang seringkali disebut sebagai kelompok support group atau parent support group untuk para orang tua yang memiliki anak ABK.

Support group merupakan tempat untuk orangorang memberi dan menerima informasi secara emosional maupun praktis. Support group banyak dilakukan dalam rangka membantu setiap orang yang memiliki permasalahan tertentu seperti para orang tua yang memiliki anak ABK, individu yang memiliki cacat tubuh atau penyakit tertentu.

Support group bisa dilakukan melalui internet atau secara tradisional dengan berkumpul dalam kelompok-kelompok tertentu di rumah atau di tempat terapi dan klinik tertentu, seperti online support group untuk anak autis yang diadakan oleh Yayasan Cinta Harapan Indonesia, temu tatap muka antarorang tua dengan atau tanpa didampingi ahli yang biasanya difasilitasi pihak klinik terapi atau sekolah.

Melalui kegiatan support group, seseorang yang mengalami masalah bisa berbagi tentang apa yang dirasakan, berbagi informasi bagaimana menangani masalah yang dihadapi, bagaimana memberikan pendidikan bagi anak yang $\mathrm{ABK}$, dan banyak hal yang bisa didapat dari kegiatan ini yang akan membantu seseorang untuk lebih bersemangat menghadapi hidup.

Bagi orang tua yang memiliki ABK, akan membantu memahami kondisi anak, mengetahui apa yang harus dilakukan untuk mengoptimalkan perkembangan anaknya, dan bisa lebih membantu menerima kondisi anak.

Dengan demikian, rumusan masalah dalam penelitian ini adalah : "Apakah terdapat perbedaan penerimaan diri orang tua ABK berdasarkan keikutsertaan dalam Support Group?".

Manfaat yang dapat diperoleh dari penelitian ini meliputi dua hal, pertama, manfaat teoretis yaitu memberikan manfaat untuk menambah informasi dalam khazanah ilmu pengetahuan khususnya bagi ilmu psikologi. Kedua, manfaat praktis yaitu menjadi masukan bagi orang tua, guru, ahli psikologi, sekolah, dan lembaga terapi dalam menyosialisasikan serta memfasilitasi kegiatan support group untuk membantu orang tua yang memiliki ABK. 


\section{KAJIAN PUSTAKA}

\section{Anak Berkebutuhan Khusus (ABK)}

Para ahli mendefinisikan anak berkebutuhan khusus adalah anak yang secara signifikan berbeda dalam beberapa dimensi yang penting dari fungsi kemanusiaannya. Anak yang secara fisik, psikologis, kognitif atau sosial terhambat dalam mencapai tujuan/ kebutuhan dan potensinya secara maksimal meliputi yang tuli, buta, mempunyai gangguan bicara, cacat tubuh, retardasi mental, dan gangguan emosional. Termasuk anak-anak yang berbakat dengan inteligensi yang tinggi, dapat dikategorikan sebagai anak khusus/ luar biasa, karena memerlukan penanganan yang terlatih dari tenaga profesional (Suran \& Rizzo, 1979 dalam Mangunsong, 2009).

Menurut Hallahan dan Kauffman (2006) (dalam Mangunsong, 2009) menyatakan bahwa siswa berkebutuhan khusus adalah anak yang memerlukan pendidikan khusus dan pelayanan terkait, jika mereka menyadari penuh kemanusiaan mereka.

Gearheart (1981) (dalam Mangunsong, 2009) mengatakan seorang anak yang dianggap berkelainan bila memerlukan persyaratan pendidikan yang berbeda dari anak-anak normal dan untuk dapat belajar secara efektif memerlukan program, pelayanan, fasilitas, dan materi khusus.

Jadi, anak berkebutuhan khusus dapat disimpulkan sebagai anak yang memiliki keterbatasan perkembangan atau terhambatnya perkembangan secara fisik, kognitif, emosi, maupun sosial termasuk anak yang memiliki kecerdasan tinggi dan berbakat, yang berbeda dari anak-anak normal serta membutuhkan penanganan, fasilitas, dan pelayanan khusus dalam pembelajarannya.

\section{Klasifikasi ABK}

Menurut Dembo (1981) (dalam Muljono, 1994), terdapat klasifikasi ABK untuk keperluan pembelajaran yaitu tunagrahita (mental retardation), kesulitan belajar, gangguan perilaku atau gangguan emosi, gangguan bicara dan bahasa, kerusakan pendengaran, kerusakan penglihatan, kerusakan fisik dan gangguan kesehatan, cacat berat dan cacat ganda, serta berkecerdasan luar biasa tinggi dan berbakat.

Dalam penelitian ini, subjek penelitian yang digunakan adalah anak berkebutuhan khusus dengan berbagai kekhususan berdasarkan klasifikasi di atas. Support Group

Support groups adalah tempat bagi seseorang untuk memberikan dan menerima ungkapan-ungkapan perasaan dan pengalaman untuk saling berbagi informasi. Seseorang dengan keadaan yang normal juga memerlukan tempat untuk saling berbagi. Begitupun dengan orang-orang yang mengalami masalah tertentu juga memerlukan tempat untuk berbagi perasan dan pengalaman dengan orang lain yang memiliki masalah yang sama (Randall, 2003).

\section{Fungsi Support Group}

Menurut Thompson (1997), beberapa fungsi dari support group berdasarkan modul yang dikembangkan The California State Department of Education mencakup membangun support; membantu saat-saat kritis dalam menghadapi masalah; memberikan reinforce positif sebagai coping perilaku; mengatasi rasa marah dan berusaha berpikir positif; berbagi informasi, ide, dan pengalaman; mengembangkan pelatihan untuk meningkatkan kemampuan tertentu; pertolongan dari para ahli; memberi kesempatan bahwa dirinya tidak sendiri; dan memiliki banyak teman baru dengan masalah yang sama untuk berbagi.

\section{Tempat Support Group}

Tempat untuk melakukan support group bisa di mana saja. Banyak tempat di rumah sakit untuk support group, di rumah individu, tempat beribadah, perpustakaan atau tempat komunitas tertentu. Selain itu, melalui media online untuk berkomunikasi jarak jauh.

\section{Frekuensi Pertemuan}

Frekuensi pertemuan tergantung tujuan dan kebutuhan setiap anggotanya, kelompok besar biasanya sebulan sekali, sedangkan kelompok kecil biasanya lebih sering seminggu sekali.

\section{Jumlah Anggota}

Jumlah anggota juga tergantung pada tujuan dan kebutuhan dari suatu kelompok dari jumlah kecil hingga besar. Jumlah kecil biasanya untuk saling berbagi pada individu yang mengalami masalah yang sama. Kelompok besar biasanya melibatkan ahli dengan mengadakan pelatihan, pendidikan, dan lainnya.

Dalam penelitian ini, peneliti tidak membedakan tempat, frekuensi, dan jumlah kelompok dalam support group.

\section{Penerimaan Diri Orang Tua}

Menurut Hurlock (1974), penerimaan diri adalah derajat dimana seseorang telah mempertimbangkan karakteristik personalnya, merasa mampu, serta bersedia hidup dengan karakteristiknya tersebut. Sedangkan Shepard (1979) mengemukakan bahwa penerimaan diri sebagai kepuasan atau kebahagiaan individu terhadap dirinya sendiri.

Jersild (Schultz, 1991) menjelaskan bahwa individu yang menerima dirinya serta mampu yakin akan standar dan prinsipnya sendiri tanpa menjadi 
budak dari pendapat orang lain dan penilaian realistis terhadap keterbatasannya tanpa menyalahkan diri sendiri. Jersild juga menyatakan bahwa penerimaan diri dipengaruhi oleh aspek eksternal seperti pandangan orang lain terhadap dirinya.

Berger berpendapat bahwa orang yang bisa menerima dirinya sendiri, akan disertai dengan penerimaannya terhadap orang lain (Denmark, 1973).

Jadi, dapat disimpulkan bahwa penerimaan diri adalah seseorang yang bisa menerima dirinya apa adanya dan merasa puas dengan segala kelebihan dan kekurangan yang dimilikinya tanpa merasa malu maupun bersalah.

Penerimaan diri orang tua yang memiliki anak berkebutuhan khusus berarti orang tua yang bisa menerima dirinya sendiri dan mengakui keterbatasannya bahwa pada kenyataannya, mereka memang memiliki anak berkebutuhan khusus tanpa merasa malu ataupun menyalahkan diri sendiri.

\section{Ciri -ciri Penerimaan Diri}

Menurut Berger (Denmark, 1973), seseorang yang memiliki penerimaan diri adalah seseorang yang memiliki ciri sebagai berikut 1) bersandar pada nilai dan standar internal dibanding eksternal;2) memiliki keyakinan bahwa mampu untuk menghadapi kehidupan; 3) bertanggung jawab dan menerima kondisi dari apa yang dilakukan dan dialaminya; 4) menerima kritik atau pujian dari orang lain secara objektif; 5) tidak berupaya menolak perasaan, motivasi, keterbatasan, kemampuan; 6) hal-hal positif dalam diri tanpa merendahkan dirinya; 7) merasa dirinya setara atau sama dengan orang lain; 8) tidak berharap orang lain menolaknya apapun alasannya; serta 9) tidak merasa dirinya berbeda dengan orang lain, tidak malu atau memiliki kesadaran diri.

\section{Faktor- faktor yang Mempengaruhi Penerimaan Orang Tua}

Menurut Hurlock (1978) terdapat beberapa faktor orang tua dapat menerima keberadaan anaknya yaitu konsep anak idaman, anak yang diharapkan oleh orang tua secara ideal, pengalaman anak dengan orang tua, nilai budaya mempengaruhi pola asuh, perkawinan yang baik dan merasa bahagia, perasaan mampu berperan sebagai orang tua, kemampuan dan kemauan menyesuaikan diri dengan pola kehidupan keluarga, alasan memiliki anak, serta cara anak bereaksi terhadap orang tua.

Sedangkan menurut Darling-Darling (1982), faktor yang mempengaruhi penerimaan atas kondisi anak adalah umur anak, status sosial ekonomi, penerimaan diri orang tua, agama, serta alasan orang tua memiliki anak.

\section{METODOLOGI PENENLITIAN}

Penelitian ini bertujuan untuk mengetahui perbedaan penerimaan diri orang tua yang memiliki anak ABK ditinjau dari keikutsertaannya dalam support group (antara yang mengikuti support group dan yang tidak mengikuti support group).

Metode yang digunakan dalam penelitian kuantitatif ini adalah metode survey, yaitu penelitian yang dilakukan pada populasi besar maupun kecil, tetapi data yang dipelajari adalah data dari sampel yang diambil dari populasi tersebut, sehingga ditemukan kejadian-kejadian relatif, distribusi, dan hubungan antarvariabel sosiologis maupun psikologis (Ridwan, 2007).

Variabel dalam penelitian ini adalah penerimaan diri orang tua yang memiliki ABK.

\section{Definisi Konseptual Penerimaan Diri}

Penerimaan diri orang tua yang memiliki anak berkebutuhan khusus berarti orang tua yang bisa menerima dirinya sendiri dan mengakui keterbatasannya bahwa pada kenyataannya memang memiliki anak berkebutuhan khusus tanpa merasa malu ataupun menyalahkan diri sendiri.

\section{Definisi Operasional Penerimaan Diri}

Total skor untuk penerimaan diri orang tua yang memiliki ABK pada penelitian ini diukur berdasarkan skala Berger yang berisi tentang ciri-ciri penerimaan diri yaitu bersandar pada nilai dan standar internal dibanding eksternal; memiliki keyakinan bahwa mampu untuk menghadapi kehidupan; bertanggung jawab dan menerima kondisi dari apa yang dilakukan dan dialaminya; menerima kritik atau pujian dari orang lain secara objektif; tidak berupaya menolak perasaan, motivasi, keterbatasan, kemampuan, hal-hal positif dalam diri tanpa merendahkan dirinya; merasa dirinya setara atau sama dengan orang lain; tidak berharap orang lain menolaknya apapun alasannya; tidak merasa dirinya berbeda dengan orang lain; serta tidak malu atau memiliki kesadaran diri.

\section{Populasi dan Sampel Penelitian}

Populasi dalam penelitian ini adalah populasi terjangkau yang diambil secara acak dari seluruh orang tua yang memiliki anak ABK di Jakarta.

Teknik sampling atau teknik pengambilan sampel yang digunakan dalam penelitian ini adalah nonprobability sampling. Adapun jenisnya adalah sampling insidental. Hal ini dilakukan dengan alasan subjek orang tua yang memiliki anak ABK di Jakarta jumlahnya terbatas. Dalam penelitian ini, jumlah sampelnya adalah 64 yang terdiri dari 32 orang pernah 
mengikuti support group dan 32 orang belum pernah mengikuti kegiatan support group.

Teknik pengumpulan data dalam penelitian ini menggunakan kuesioner tentang penerimaan diri orang tua yang memiliki ABK dengan skala Berger (Berger Self Acceptance Scale (BSAS)) (Berger dalam Denmark, 1973) yang telah diadaptasi ke dalam bahasa Indonesia oleh peneliti.

Selain menggunakan kuesioner untuk mengetahui penerimaan diri, dalam penelitian ini digunakan pula kuesioner untuk mengetahui keikutsertaan orang tua yang memiliki ABK dalam kegiatan support group dengan pertanyaan terbuka.

Perhitungan reliabilitas instrumen dalam penelitian ini menggunakan reliabilitas internal alpha cronbach menggunakan SPSS v 16 yang hasilnya akan dibandingkan dengan kaidah reliabilitas Guilford untuk menentukan apakah instrumen yang digunakan reliabel atau tidak. Dalam penelitian ini, peneliti menggunakan instrumen terpakai atau try out terpakai. Hal ini dikarenakan keterbatasan jumlah subjek.

Sebelum dilakukan analisis data, terlebih dahulu diperlukan uji prasyarat analisis data sebagai prasyarat teknik analisis data yang digunakan, yaitu dengan uji homogenitas yang dilanjutkan dengan pengujian hipotesis menggunakan SPSS v 16.00. Uji homogenitas menggunakan Levene's test. Data dinyatakan homogen, jika signifikan (p) lebih besar dari á $(0,05)$. Sedangkan uji hipotesisnya menggunakan independent sample t-test.

\section{HASIL DAN PEMBAHASAN}

\section{Data Skor Penerimaan Diri}

Nilai rata-rata untuk skor penerimaan diri orang tua yang memiliki anak ABK dan mengikuti support group adalah 101,81. Nilai maksimum empiris yang diperoleh adalah 127 dan nilai minimumnya adalah 78. Sementara, pada orang tua yang memiliki ABK tetapi tidak atau belum pernah mengikuti support group rata-ratanya tidak jauh berbeda dengan yang pernah mengikuti support group yaitu 101,03. Nilai maksimum empiris yang diperoleh adalah 127 dan nilai minimumnya adalah 73 .

\section{Pengujian Reliabilitas Instrumen}

Berdasarkan uji reliabilitas dengan menggunakan SPSS v 16.00 dengan rumus alpha diperoleh bahwa reliabilitas internal dari instrumen penerimaan diri adalah sebesar 0,874 sehingga instrumen tersebut dapat dikatakan reliabel berdasarkan koefiesien reliabilitas dari Guilford.

\section{Uji Homogenitas}

Hasil uji homogenitas dalam penelitian ini menggunakan Uji Levene's Test adalah $\mathrm{F}=0,755$ $\mathrm{p}=0,388 ; \mathrm{p}>0.05$, maka data homogen.

\section{Pengujian Hipotesis}

Dari hasil perhitungan independent sample t-test diperoleh hasil $t$ hitung sebesar 0,267. Untuk harga $t$ tabel á $=0.05$ sebesar 2 . Oleh karena t hitung $(0.267)<$ dari t tabel á $=0.05$ (2) dan p > 0,05 maka H0 diterima dan H1 ditolak. Dengan demikian, tidak terdapat perbedaan yang signifikan pada penerimaan diri orang tua yang memiliki ABK berdasarkan keikutsertaan dalam support group (antara yang pernah mengikuti support group dan yang belum pernah mengikuti kegiatan support group).

Berdasarkan hasil data deskripsi skor penerimaan diri, diketahui bahwa mean yang diperoleh responden yang mengikuti support group $(101,81)$ lebih tinggi dibandingkan yang tidak mengikuti kegiatan support group $(101,03)$, meskipun perbedaan meannya hanya sedikit. Hal ini menunjukkan kegiatan support group dapat lebih membantu orang tua menerima dirinya atas kondisi anaknya yang ABK. Sedangkan perbedaan mean yang hanya sedikit, menunjukkan bahwa orang yang belum pernah mengikuti kegiatan support group, juga bisa menerima diri atas kondisi anaknya yang $\mathrm{ABK}$, karena adanya beberapa faktor yang mempengaruhi seperti dukungan keluarga, lingkungan, serta agama.

Status ekonomi responden yang tergolong menengah ke bawah, menurut Darling-Darling (1982) cenderung lebih bisa menerima diri atas kondisi anaknya yang ABK dibandingkan pada status ekonomi yang lebih tinggi sehingga antara orang tua yang pernah dan tidak pernah mengikuti kegiatan support group tidak ada perbedaan penerimaan diri.

\section{Keterbatasan Penelitian}

Keterbatasan dalam penelitian ini adalah sampel yang jumlahnya terbatas membuat generalisasi hasil kurang dapat dilakukan. Selain itu, karena keterbatasan subjek juga, peneliti tidak melakukan uji coba instrumen, melainkan menggunakan instrumen terpakai dari instrumen yang telah diadaptasi ke dalam bahasa Indonesia oleh peneliti dari skala Berger (Berger Self Acceptance Scale (BSAS)) (Berger dalam Denmark, 1973).

\section{PENUTUP}

\section{Kesimpulan}

Berdasarkan analisis data yang dilakukan dapat 
disimpulkan bahwa tidak terdapat perbedaan skor penerimaan diri orang tua yang memiliki ABK berdasarkan keikutsertaannya dalam kegiatan support group (antara yang mengikuti kegiatan support group dengan yang belum pernah mengikuti kegiatan support group). Terdapat beberapa hal yang mempengaruhi tidak adanya penerimaan diri orang tua yang memiliki ABK pada yang pernah mengikuti kegiatan support group maupun belum pernah mengikuti kegiatan support group yaitu adanya dukungan dari keluarga, lingkungan, agama serta status sosial ekonomi.

Saran

Menyosialisasikan sarana atau kegiatan yang dapat membantu para orang tua untuk bisa lebih memahami dan menerima kondisi anaknya yang ABK sehingga dapat mengoptimalkan perkembangan anak. Salah satu sarana yang bisa dijadikan pertimbangan adalah kegiatan support group.

Perlu adanya penelitian lebih lanjut tentang kegiatan support group terkait dengan fungsinya untuk memfasilitasi orang tua yang memiliki anak berkebutuhan khusus. Dengan tujuan untuk dapat mengembangkan model kegiatan support group yang tepat dengan masyarakat Indonesia.

\section{DAFTAR PUSTAKA}

Darling, D. (1982). Children who are different meeting the challenges of birth defects in society. London: C.V. Mosby Company.
Denmark, K.L. (1973). Selfacceptance El leader effectiveness. Journal of Extension. Texas A \& M University

Hurlock, E.B. (1978). Perkembangan anak jilid 2. Edisi Keenam. Alih bahasa: Med Meitasari Tjandrasa. Jakarta : Erlangga

Mangunsong, F. (2009). Psikologi dan pendidikan anak berkebutuhan khusus. Jilid Kesatu. Jakarta : LPSP3 UI

Mulyono, A. \& Sudjadi. (1994). Pendidikan luar biasa umum. Jakarta: DEPDIKBUD.

Randall, M. C. (2003). Support group what they are $\mathcal{E}$ what they do. Diakses pada tanggal 10 Juli 2010 dari http:/ / www.genetichealth.com/Resources_Suppar_Groups_What_They_Are_and_What_They_Doshtml.

Ridwan. (2007). Belajar mudah penelitian untuk guru, karyawan dan peneliti muda. Bandung: Alfabeta.

\section{KETERANGAN PENULIS}

Iriani Indri Hapsari, saat ini sebagai dosen tetap di jurusan Psikologi Fakultas Ilmu Pendidikan Universitas Negeri Jakarta.

Herdiyan Maulana dilahirkan Semarang pada tanggal 30 Desember 1982. Saat ini sebagai pengajar di jurusan Psikologi Fakultas Ilmu Pendidikan Universitas Negeri Jakarta. 